адъюнкт факультета подготовки научно-педагогических кадров

Академии права и управления Федеральной службь исполнения наказаний России

\section{НЕСОВЕРШЕННОЛЕТНИЕ ОСУЖДЕННЫЕ С СОЦИАЛЬНО ЗНАЧИМЫМИ ЗАБОЛЕВАНИЯМИ: ПРОБЛЕМЫ ИСПОЛНЕНИЯ НАКАЗАНИЯ В ВИДЕ ЛИШЕНИЯ СВОБОДЫ И ИХ СОЦИАЛЬНОЙ РЕАБИЛИТАЦИИ}

\begin{abstract}
Аннотация:
В статье раскрываются особенности исполнения наказания в виде лишения свободы в отношении несовершеннолетних осужденных, больных соци ально значимыми заболеваниями, а также их социальной реабилитации в аспекте реформирования уголовно-исполнительной системы Российской Федерации. Автором проанализирована статистическая информация Федеральной службы исполнения наказаний о заболеваемости данной категории осужденных, а также обозначены объективные причины высокого показателя социально значимых заболеваний в воспитательных колониях. Сделань выводы о том, что исправление совместно с лечением несовершеннолетних осужденных, больных социально значимыми заболеваниями, требует целенаправленного и эффективного воздействия на основные факторы в воспитательных колониях вызывающие и поддерживающие эти заболевания. Кроме того, необходимо обеспечение их необходи мой медицинской помощью после освобождения из мест лишения свободы.
\end{abstract}

Ключевые слова:

воспитательные колонии, несовершеннолетние осужденные, социально значимые заболевания, условия отбывания наказаний, здоровье несовершеннолетних осужденных, освободившиеся осужденные, социальная адаптация, ресоциализация
Postgraduate student Academic Personnel's Training Department, Academy of Law Management of the Federal Penal Service of Russia

\section{JUVENILE OFFENDERS SUFFERING FROM SOCIALLY SIGNIFICANT DISEASES: PROBLEMS OF EXECUTING THE IMPRISONMENT AND THEIR SOCIAL REHABILITATION}

Summary:

The study reveals the peculiarities of executing the im prisonment of juvenile offenders suffering from socially significant diseases and their social rehabilitation in terms of reforming the penal system of the Russian Federation. The author analyzes the statistical data of the Federal Penal Service on the disease rate of this category of convicted persons and notes the objective reasons for the high rate of socially significant diseases in juvenile correctional facilities. It is concluded that the correction along with the treatment of juvenile offenders suffering from socially significant diseases requires a targeted and effective control over the key factors causing and sustaining these diseases in such detention facilities. In addition, one should provide the above-mentioned convicts with the basic medical care after their release from prison.

Keywords

juvenile correctional facilities, juvenile offenders, socially significant diseases, conditions for serving sentences, health of juvenile offenders, released prisoners, social adaptation, resocialization.

Преобразования уголовно-исполнительной системы России, направленные на гуманизацию и приближение условий отбывания наказания к международным стандартам соблюдения прав человека, затронули порядок и условия организации исполнения наказаний в воспитательных колониях. Высокую озабоченность руководства исправительных учреждений, а также медицинских работников вызывают несовершеннолетние осужденные с социально значимыми заболеваниями.

Несмотря на то что детское население страны подлежит 100 \%-му диспансерному наблюдению, многие из числа несовершеннолетних осужденных впервые узнают о своем заболевании при поступлении в следственные изоляторы или воспитательные колонии. Почти у каждого второго есть различные хронические заболевания, выявленные именно в период поступления в воспитательную колонию [1, с. 29].

По материалам Федеральной службы исполнения наказаний, общее количество зарегистрированных заболеваний в воспитательных колониях в 2016 г. составило 5577, из них с впервые установленным диагнозом - 2690. Так, в частности, серьезной проблемой является прогрессирование и рост пагубных зависимостей несовершеннолетних, поступающих в исправительные учреждения, что сказывается на их психическом и соматическом здоровье. О неблагоприятных тенденциях в воспитательных колониях в 2016 г. свидетельствует увеличение доли лиц, страдающих наркотической зависимостью, - 11,44 \% (2014 г. - 4,62 \%), алкогольной зависимостью, - 6,74 \% (2014 г. 3,98 \%), а также больных психическими расстройствами - 63,34 \% (2014 г. - 39,97 \%). 
Ухудшение психического здоровья несовершеннолетних осужденных связано прежде всего с недостаточной социальной адаптацией, проявляющейся в частом нарушении поведения подростка - от повышения конфликтности до совершения правонарушений.

Современная клиническая типология психических расстройств у несовершеннолетних, ассоциированных с пенитенциарным стрессом, их своевременное выявление, медико-психологическая коррекция имеют большое значение в плане превенции, охраны психического здоровья несовершеннолетних осужденных.

Процесс адаптации к социуму достаточно сложен для освободившихся из мест лишения свободы, а особенно для несовершеннолетних, имеющих психические отклонения, состояние которых усугубляется еще и под влиянием пенитенциарного стресса и является психотравмирующим звеном в их личностном развитии [2, с. 56].

К сожалению, встречаются случаи грубого отношения к психически нездоровым воспитанникам колоний со стороны сотрудников уголовно-исполнительной системы, что воспринимается несовершеннолетними крайне негативно. Поэтому для работы с такой трудной категорией несовершеннолетних требуются квалифицированные специалисты, постоянно повышающие профессиональный уровень, способные качественно и эффективно осуществлять обучение воспитанников. Работа по отбору кандидатов на службу, а также занятия с действующими сотрудниками уголовно-исполнительной системы, разработка мероприятий по сокращению текучести кадров способствуют формированию в воспитательных колониях стабильного служебного коллектива.

По материалам Федеральной службы исполнения наказаний, в воспитательных колониях в 2016 г. также отмечается рост выявленных инфекций, передающихся преимущественно половым путем: ВИЧ-инфекция - 0,78 \% (2014 г. - 0,44 \%), сифилис - 0,59 \% (2014 г. - 0,25 \%). 3aфриксированы единичные случаи туберкулеза.

Значительной доле заболеваний, передающихся половым путем, среди несовершеннолетних осужденных, поступающих в исправительные учреждения, способствует отсутствие у них элементарных гигиенических навыков. Инфекции, передающиеся половым путем, надлежит во многом расценивать как болезни поведения. К особенностям, которые выделяют несовершеннолетних осужденных, больных инфекциями, передающимися половым путем, из общего числа лиц, содержащихся в воспитательных колониях, и позволяют различить их медико-социальный портрет, относятся: проживание в трудных семьях с алкогольной зависимостью, психопатологические черты характера, которые усугубляются на фоне безнадзорности, злоупотребления до приговора алкоголем и употребления наркотических средств, что и приводит к криминогенному поведению. Психические заболевания и сексуальные девиации нередко становятся причиной заболеваний, передающихся половым путем среди несовершеннолетних осужденных. Несмотря на кажущуюся безобидность заболеваний, передающихся половым путем, в будущем они могут привести к тяжелым последствиям, стойким нарушениям репродуктивного здоровья, особенно в подростковом возрасте.

В связи с этим требуется значительная работа по созданию надлежащих гигиенических условий в основных сферах жизнедеятельности осужденных в воспитательных колониях, повышению уровня санитарной культуры и гигиенического воспитания несовершеннолетних осужденных, что будет способствовать осознанному отношению несовершеннолетнего к своему здоровью и личной безопасности.

В воспитательных колониях отмечается прогрессивное нарастание числа ВИЧ-инфицированных осужденных, что является своего рода отражением ситуации по ВИЧ-инфекции в целом по стране.

Заражение ВИЧ-инфекцией влечет за собой серьезные нарушения эмоционального характера у несовершеннолетних осужденных, у них появляется агрессивность по отношению к обществу. На работников всей уголовно-исполнительной системы в данном случае ложится большая ответственность, так как они могут уберечь от неправильных действий ВИЧ-инфицированных, воздействуя на их психическое состояние. Важно дать почувствовать инфицированному, что он такой же человек, как и все другие, и помочь такому несовершеннолетнему адаптироваться.

Сложной проблемой является отношение здоровых осужденных к ВИЧ-инфицированным. Часто подростки скрывают свои заболевания от других осужденных, однако в условиях ограниченного пространства это сложно осуществить. В большинстве своем здоровые подростки относятся отрицательно к больным осужденным, что приводит к конфликтным ситуациям в воспитательной колонии.

Вследствие дискриминации, связанной с ВИЧ-инфекцией, права осужденных, живущих с этим заболеванием, нарушаются, хотя законные основания для этого отсутствуют. Тем не менее обеспечение законодателем, администрацией воспитательных колоний всех элементов правового статуса осужденных несовершеннолетних предопределяет эффеектиность исполнения уго- 
ловного наказания в виде лишения свободы [3, с. 8]. Поэтому необходимо постоянно осуществлять специальные программы по обучению сотрудников уголовно-исполнительной системы профилактике ВИЧ-инфекции и формированию в среде несовершеннолетних осужденных положительного отношения к ВИЧ-инфицированным.

Одной из актуальных проблем остается низкая приверженность ВИЧ-инфицированных к высокоактивной антиретровирусной терапии - лечению, которое назначается пожизненно, непрерывным курсом. Такое отношение с их стороны обусловлено недоверием к назначаемому лечению, низкой информированностью пациентов, психологическими проблемами человека, которому необходимо преодолеть тревогу, страх, стресс, обрести чувство доверия и безопасности. В связи с этим нужно проводить постоянную разъяснительную работу среди несовершеннолетних осужденных и оказывать дополнительную психологическую помощь ВИЧ-инфицированным.

Приоритетными в современных условиях должны быть методы активного выявления и профилактики туберкулеза среди несовершеннолетних осужденных, для успешного проведения которых необходимо уделять существенное внимание повышению резистентности пациентов к инфекции, где главная роль принадлежит созданию противотуберкулезного иммунитета за счет иммунизации вакцинами.

Воспитательные колонии должны поддерживать и укреплять тесные контакты с гражданской системой здравоохранения: проводить совместные мероприятия, обеспечивать преемственность лечебного процесса, внедрять единую учетно-отчетную документацию, что, несомненно, даст хорошие результаты в борьбе с туберкулезом.

Таким образом, проблемы ухудшения состояния здоровья несовершеннолетних осужденных с социально значимыми заболеваниями стоят достаточно остро. Как показывают исследования, общее физическое и психическое развитие таких подростков значительно отличается от развития других здоровых осужденных. Нередко у осужденных, больных социально значимыми заболеваниями, ниже уровень интеллектуального развития, беднее эмоциональная сфера, в связи с чем позднее и хуже формируются навыки саморегуляции и правильного поведения.

В целях эффективного участия в профилактике социально значимых заболеваний всех институтов гражданского общества в воспитательных колониях следует максимально использовать потенциал бесед, лекций с приглашением представителей общественности для их проведения, что внесет серьезный вклад в оздоровление несовершеннолетних осужденных. Необходим постоянный мониторинг состояния физического развития и здоровья несовершеннолетних, который обеспечил бы выявление причинно-следственных связей между физическим состоянием осужденных, факторами среды их обитания и социально-экономическими условиями жизни.

Социальная адаптация больных социально значимыми заболеваниями подростков практически всегда определяется не только степенью заболевания, но и особенностями их поведения. Несамостоятельные, слабовольные несовершеннолетние с социально значимыми заболеваниями чувствуют себя беспомощными, усталыми, неспособными справиться с жизненными трудностями. Агрессивное поведение может возникнуть у таких несовершеннолетних в ответ на обиды и наказания, оно выражается в нанесении себе членовредительства.

Ресоциализация несовершеннолетних осужденных, больных социально значимыми заболеваниями, - одна из самых острых социальных проблем. Укрепить здоровье и сберечь от повторных преступлений подростков - значит проявить реальную заботу об охране и пополнении интеллектуального потенциала общества. В связи с этим умение заботиться о своем здоровье становится важным фактором в жизни освобожденных несовершеннолетних осужденных, имеющих социально значимые заболевания.

Ресоциализацию несовершеннолетних осужденных правомерно увязывать с решением вопросов социально-правовой защиты подростков [4, с. 218]. Если в период отбывания наказания в воспитательной колонии медицинское обслуживание (диагностика, лечение, профилактика заболеваний) было обязательным сопровождением больного осужденного, то после освобождения молодые люди сталкиваются с необходимостью самостоятельно заботиться о своем здоровье. Эта проблема заключается в разрыве оказания медицинской помощи в процессе отбывания наказания и после освобождения лица из исправительного учреждения [5, с. 216].

Опыт сотрудников в воспитательных колониях, данные психологических и других научных исследований показывают, что при освобождении из исправительного учреждения несовершеннолетние с социально значимыми заболеваниями оказываются плохо приспособленными к самостоятельной жизни. После освобождения несовершеннолетнему часто бывает не к кому обратиться и узнать элементарную информацию (например, к какому именно врачу обратиться при определенной болезни, как получить направление на обследование, в больницу и т. д.), поэтому необходимо просвещать больных осужденных в области заботы о своем здоровье. 
Несовершеннолетние осужденные, больные социально значимыми заболеваниями, к сожалению, в основном не хотят приучаться к труду, самообслуживанию, заботиться о себе. Поэтому такие подростки часто становятся жертвами мошенников и криминальных структур, редко заводят друзей и семью, а от одиночества и непонимания находят утешение в алкоголизме, наркомании, противоправных действиях, становятся пациентами психотерапевтических и наркологических диспансеров. Нередко несовершеннолетние осужденные с социально значимыми заболеваниями после освобождения из мест лишения свободы становятся бомжами, пополняют ряды преступников, заканчивают жизнь самоубийством.

Все это свидетельствует о сложности задач, стоящих перед начальниками отрядов, психологами, социальными работниками воспитательной колонии, а также о необходимости актуализации работы психиатра, пересмотра всех имеющихся в арсенале сотрудников форм, методов и технологий исправления совместно с лечением в использовании дифференцированного подхода к несовершеннолетним осужденным, имеющим социально значимые заболевания, и необходимости эффрективного и преемственного постпенитенциарного сопровождения.

\section{Ссылки:}

1. Половникова А.А., Давыдова Н.В. Оценка состояния здоровья осужденных в воспитательных колониях, участвующих в эксперименте по апробации модели воспитательного центра // Ведомости уголовно-исполнительной системы. 2013. № 4 (131). C. 28-33.

2. Калинина Т.В., Кораблева К.А., Кораблева И.Г. К проблеме ресоциализации несовершеннолетних осужденных // Молодой ученый. 2015. № 23.2. С. 55-58.

3. Кашуба Ю.А., Бакаева Ю.В. Уголовные наказания, применяемые в отношении несовершеннолетних : монография. СПб., 2009. 125 c.

4. Шабанов В.Б. Профилактика противоправного поведения несовершеннолетних // Актуальные вопросы уголовно-исполнительного права, криминологии и исполнения наказаний : тез. докл. Междунар. науч.-практ. конф. (Минск, 28 мая 2015 г.) / отв. ред. В.Б. Шабанов. Минск, 2015. С. 217-222.

5. Крымов А.А., Скиба А.П. Исполнение лишения свободы в отношении больных осужденных : монография / под общ. ред. Ю.А. Кашубы. Рязань, 2015. 258 с.

\section{References:}

Kalinina, TV, Korableva, KA \& Korableva, IG 2015, 'Concerning the problem of resocialization of juvenile convicts', Molodoy uchenyy, no. 23.2, pp. 55-58, (in Russian). sian).

Kashuba, YuA \& Bakaeva, YuV 2009, Criminal penalties applicable to minors, monograph, St. Petersburg, 125 p., (in Rus-

Krymov, AA, Skiba, AP \& Kashuba, YuA (ed.) 2015, Execution of imprisonment in relation to sick convicts, monograph, Ryazan, 258 p., (in Russian).

Polovnikova, AA \& Davydova, NV 2013, 'Assessment of the health status of convicts in educational colonies being a part of an experiment to test the model of an educational center', Vedomosti ugolovno-ispolnitel'noy sistemy, no. 4 (131), pp. 28-33, (in Russian).

Shabanov, VB (ed.) 2015, 'Prevention of illegal behavior of minors', Aktual'nyye voprosy ugolovno-ispolnitel'nogo prava, kriminologii i ispolneniya nakazaniy: tez. dokl. Mezhdunar. nauch.-prakt. konf. (Minsk, 28 maya 2015 g.), Minsk, pp. 217-222, (in Russian). 